\title{
PEMODELAN PERTUMBUHAN TANAMAN ZINNIA MENGGUNAKAN LINDENMAYER SYSTEM DENGAN MATHEMATICA
}

\author{
Suhartono \\ Jurusan Teknik Informatika UIN Maulana Malik Ibrahim Malang \\ Email : galipek@gmail.com
}

\begin{abstract}
ABSTRAK
Pendekatan dalam mempelajari pemodelan pertumbuhan tanaman saat ini adalah dengan menggunakan metoda L-System yaitu sistem penulisan berulang (rewriting system) yang dilakukan secara paralel dengan menggunakan aturan gramatikal. Dengan menggunakan software Mathematica telah diidentifikasi pemodelan pertumbuhan tanaman zinnia sebanyak 6 tahap pertumbuhan selama 25 hari dan dapat divisualisasikan.
\end{abstract}

Kata kunci : Identifikasi, Pemodelan pertumbuhan tanaman zinnia , L-System

\section{ABSTRACT}

The approaches in the study of plant modelling growth at this time is using the method of L-system, that is a system of repetitive writing repetitive performed in parallel by using grammatical rules. By using Mathematica this modeling has been identified as 6 zinnia plant growth during the growth phase of 25 days and can be visualized.

Keywords: Identification, Modeling plant growth zinnia, L-System

\section{PENDAHULUAN}

Pendekatan tentang arsitektur tanaman telah dapat dikategorikan sebagai model tanaman. Arsitektur tanaman dapat direpresentasikan dalam bentuk grafika 3D. Aristid Lindenmayer menjelaskan teori pertumbuhan sel anabaena catenula dengan menggunakan sistem penulisan berulang (rewriting system) dan dilakukan secara paralel yang dinyatakan dengan menggunakan aturan gramatikal yang disebut sebagai metoda $L$ System (Prusinkiewics, dkk, 1990). Kemudian metoda L-System banyak diterapkan untuk pemodelan berbagai jenis tanaman (Prusinkiewics, dkk, 2003; Pachepsky, dkk, 2004; Hirafuji, 1991; Somporn, 2004; Suhartono, dkk, 2011).

Pengembangan metoda L-System untuk menggambarkan pertumbuhan tanaman berdasarkan karakteristik lingkungan menjadi pemodelan tanaman secara realistik (Mech dkk, 1996; Chuai-Aree dkk, 2000; Suyanto, dkk, 2010, Suhartono, dkk, 2011, Suhartono, dkk, 2013).

Hasil penelitian yang dihasilkan adalah identifikasi pemodelan pertumbuhan tanaman zinnia dengan metoda L-System yang mendekati tanaman secara real. Pemodelan pertumbuhan tanaman yang dihasilkan dapat mengidentifikasi 6 tahap proses pertumbuhan tanaman zinnia.

\section{DATA PERCOBAAN}

Penelitian dilakukan di Laboratorium Jaringan Komputer Jurusan Teknik Informatika UIN Maliki Malang. Data pertumbuhan tanaman dipakai tanaman kembang kertas (Zinnia Elegane Jacq), penanaman dilakukan dengan polibag sejumlah 3 tanaman zinnia sebagai data untuk digunakan menyusun pemodelan pertumbuhan tanaman. Sedangkan faktor-faktor lingkungan yang meliputi suhu dan kelembaban lingkungan, intensitas cahaya, pemupukan dan faktor lingkungan dalam penelitian ini lebih bersifat sebagai data pendukung terhadap pengamatan pertumbuhan tanaman zinnia. Pemupukan dilakukan dengan cara mencampur pupuk dengan air sebanyak 5 liter untuk setiap kelompok tanaman. Pengukuran dilakukan pengamatan hingga hari yang ke 25 dengan interval pengamatan selama 5 hari terhadap indikator pertumbuhan struktur model tanaman meliputi panjang batang, diameter batang, tinggi daun, lebar daun, diameter bunga, dan tinggi tanaman.

\section{PEMODELAN PERTUMBUHAN TANAMAN}

Perkembangan penelitian pemodelan pertumbuhan tanaman dimulai saat Aristid Lindenmayer memperkenalkan teori 
pertumbuhan cell anabaena catenula dengan menggunakan rewriting string telah diidentifikasi sebagai metoda Lindenmayer System (L-System) ( Prusinkiewics, dkk, 1990). Kemudian diperbaiki dan dirancang menjadi pemodelan pertumbuhan secara realistik pada tanaman tinggi (Prusinkiewics, dkk, 2003). Penerapan metoda $L$ System telah ditingkatkan sebagai alat pemodelan pada berbagai jenis tanaman (Pachepsky, dkk, 2004).

Metoda L-System yang disebut teori rewriting string adalah pola aturan (grammar) yang dijumpai pada tanaman yang bersifat sebagai pola yang memiliki kesamaan dan berulang. Sintak terhadap pertumbuhan tanaman dalam metoda L-System akan dinotasikan dan disusun dalam kaidah aturan (rules) pertumbuhan tanaman. Pada kondisi sesungguhnya tanaman yang mengalami pertumbuhan akan diawali dari bibit, kemudian pertumbuhan tanaman dilanjutkan dengan tumbuhnya tunas muda yang dinotasikan sebagai axiom pada metoda L-System. Aturan reproduksi tanaman diberikan pada tahap tunas muda yang tumbuh dan berkembang, kemudian disusul oleh batang yang kemudian diikuti oleh daun muda, kesemuanya berkembang secara paralel, terakhir adalah bunga. Pengembangan pemodelan pertumbuhan tanaman untuk mendapatkan variasi model pertumbuhan yang sesuai dengan keinginan dengan memodifikasi sintak pada pertumbuhan tanaman pada metoda $L$-System dilakukan dengan metoda Genetic L-System Programming.

Piranti lunak untuk memodelkan pertumbuhan tanaman, pertama piranti lunak $L$ Studio (Karwowski.R dkk, 2006) merupakan perangkat lunak pemodelan pertumbuhan tanaman yang dikembangkan di Universitas Calgary tahun 1999 bersifat komersial. Bahasa yang dikembangkan adalah bahasa $\mathrm{C}++$ yang ditambahkan format L-System dengan notasi format bahasa $\mathrm{L}+\mathrm{C}$. Piranti lunak Plant VR (Somporn.C.A dkk, 2004) merupakan piranti lunak pertumbuhan tanaman untuk parametric $L$ System sebagai contoh untuk tanaman kedelai, bahasa pemrograman yang dikembangkan adalah bahasa Pascal. Piranti lunak Mathematica dengan aplikasi kLSystems dan Evolvica (Jacob.C, 1995) merupakan piranti lunak pemodelan pertumbuhan tanaman dan evolusi pemodelan pertumbuhan tanaman sebagai contoh untuk tanaman bunga lychnis coronaria.

\section{METODA L-SYSTEM}

Metoda Lindenmayer System (L-System) adalah aturan formal yang disusun sebagai gramatika dalam bentuk axioma, dimana simbolsimbol yang digunakan merepresentasikan pertumbuhan tanaman, terjadi pergantian simbol secara paralel dan simultan pada masing-masing tahap. Disini perbedaan penting gramatika Chomsky dan L-System terletak pada hal produksi. Di gramatika Chomsky produksi dipakai sebagai urutan (sequentiallly) sedangkan pada gramatika L-System produksi dipakai sebagai paralel dan simultan untuk mengganti komponen. Ini akibat dari refleksi motivasi biologi, dimana produksi adalah pertumbuhan, deferensiasi sel dan morfogenesis.

\section{REWRITING SYSTEM}

Konsep utama dari Lindenmayer System adalah penulisan berulang. Penulisan berulang adalah teknik untuk mendifinisikan objek secara kompleks dengan cara mengganti bagian dari objek dengan cara rewriting rule atau production (Prusinkiewics, dkk, 1990). Contoh dari objek grafika yang didefinisikan secara aturan rewriting rule adalah snowflake curve, pada tahun 1905 oleh von koch (Prusinkiewics, dkk, 1990). Proses dari rewriting rule terdapat dua bagian pembentukan yaitu initiator dan generator. Dimana menerapkan generator pada initiator, kemudian menerapkan generator pada hasil yang terakhir, dan seterusnya. Dimana menerapkan generator pada initiator, kemudian menerapkan generator pada hasil yang terakhir, dan seterusnya. Jika digunakan $\triangle$ sebagai initiator dan $\triangle$ sebagai generator setelah satu iterasi didapat<smiles>C1CCCCCCCCCCCCCCC1</smiles>

, dimana mengganti setiap baris dengan generator, dapat di lihat pada gambar 1 .
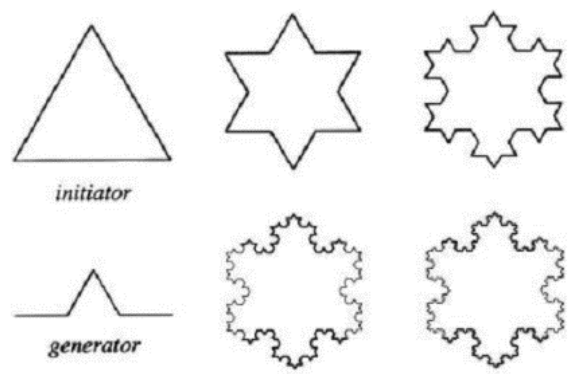

Gambar 1. Konstruksi dari kurva snowflake (Prusinkiewics.P, dkk, 1990)

\section{STRUKTUR PEMODELAN PERTUMBUHAN TANAMAN ZINNIA}

Data biologi tanaman didapat dari pengamatan pertumbuhan tanaman zinnia untuk membangun simulasi pertumbuhan tanaman 
zinnia. Diagram alir untuk model tanaman zinnia dan visualisasi pertumbuhan tanaman zinnia dapat dilihat pada gambar 2 .

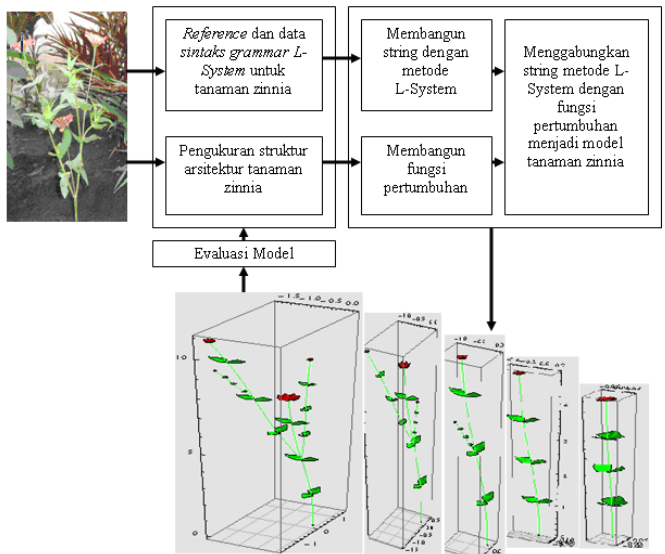

Gambar 2. Diagram dari model pertumbuhan dan visualisasi tanaman zinnia

Gambar 2 menjelaskan tentang prototipe dari model pertumbuhan dan visualisasi tanaman zinnia menggunakan metoda L-System dan menggabungkan model matematika dengan data bilogi dari struktur arsitektur tanaman zinnia. Metoda L-System digunakan untuk model kualitatif yang dibangun untuk merepresentasikan bangunan dan topologi bagi tanaman zinnia. Diagram ini memiliki enam blok, (1) mendifinisikan model kualitatif yang dibangun dari pengamatan pertumbuhan tanaman zinnia dalam siklus hidup tanaman zinnia, (2) mengukur karakteristik tanaman zinnia yang dikumpulkan dari data tanaman dilapangan, (3) mengubah data mentah menjadi fungsi pertumbuhan tanaman berdasarkan perkiraan fungsi pada setiap struktur tanaman zinnia, (4) mendefinisikan model kuantitatif yang terdiri dari model kualitatif dan fungsi pertumbuhan tanaman, memvisualisasikan model kuantitatif , dan (6) mengevaluasi model kuantitatif.

\section{MODEL KUALITATIF}

Proses pemodelan dimulai dengan menggunakan model kualitatif. Dimana mengambil data dari pertumbuhan tanaman dan melakukan pengamatan, pengamatan ini akan mengetahui topologi dan urutan pertumbuhan (Prusinkiewicz, dkk, 1990) dari modul pada arsitektur tanaman zinnia.

Untuk memproduksi daun tanaman zinnia dimulai setelah tunas, kemudian batang sebagai dasar dari munculnya sepasang daun, kemudian muncul sepasang daun, kemudian muncul daun yang dikuti oleh kuncup bunga jalur ini adalah sebagai batang utama, kemudian muncul dua tunas pada ketiak daun pada order ke dua sebelum daun terakhir yang dekat dengan kuncup bunga. Pada notasi p3 menjelaskan pertumbuhan sepasang daun pada setiap batang sampai pucuk tunas sebelum berbunga. Maka model tanaman zinnia dapat dinotasikan

$$
\begin{aligned}
& \omega: \mathrm{A} 4 \\
& \text { p1 }: \mathrm{A} 4 \rightarrow \mathrm{I}[\mathrm{A} 2][\mathrm{A} 2] \mathrm{IK} 0 \\
& \text { p2 }: \mathrm{Ai} \rightarrow \mathrm{Ai}+1,0 \leq \mathrm{i}<4 \\
& \text { p3 }: \mathrm{Li} \rightarrow \mathrm{Li}+1,0 \leq \mathrm{i}<4 \\
& \text { p4 }: \mathrm{Ki} \rightarrow \mathrm{Ki}+1, \mathrm{i} \geq 0
\end{aligned}
$$

Model tanaman zinnia tersebut akan dibangun model tanaman dengan menggunakan metoda DOL-System, yaitu komponen tanaman zinnia adalah himpunan dari struktur komponen, hubungan komponen dan proses pertumbuhan komponen yang dapat dinotasikan sebagai $\mathrm{G}_{\text {zinnia }}=\left(\sum, \mathrm{P}=\left\{\mathrm{p}_{1}, \ldots, \mathrm{p}_{9}\right\}, \alpha\right), \quad$ dimana $\quad \sum$ adalah alphabet dimana $\sum=\left(\delta_{1}, \ldots, \delta_{n}\right)$, setiap simbol alphabet mewakili unit morfologi seperti sprout,stalk,leaf, bloom, $\alpha$ adalah string awal, disebut sebagai aksioma dan $\mathrm{P}=\left(\mathrm{p}_{1}, \ldots, \mathrm{p}_{\mathrm{n}}\right)$, a set of productions or rewrite rules. Produksi pertama adalah menjelaskan tentang hubungan antar komponen yang mendasari dari model kualitatif dimana notasi tunas adalah sprout, kemudian noasi batang adalah stalk, kemudian noasi daun adalah leaf dan kemudian notasi bunga adalah bloom

$$
\begin{aligned}
& \mathrm{p}_{1}=\operatorname{sprout}(4) \rightarrow \mathrm{f} \operatorname{stalk}(3)[\operatorname{leaf}(1)] \mathrm{f} \\
& \operatorname{stalk(2)\quad [leaf(1)]} \\
& \text { [sprout (2)] } \\
& \text { [sprout (2)] } \mathrm{f} \\
& \operatorname{stalk(1)} \text { bloom(0) }
\end{aligned}
$$

notasi lengkap dengan metoda DOL-System untuk model kualitatif dapat dilihat pada gambar 3 .

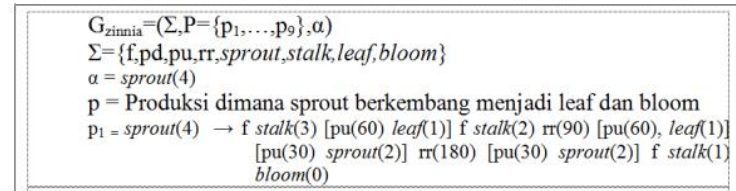

Gambar 3. Struktur model kualitatif tanaman zinnia dengan metoda L-System.

\section{MODEL KUANTITATIF}

Model kuantitatif pada penelitian ini adalah mengkombinasikan string $L$-System pertumbuhan tanaman zinnia dari model kualitatif dengan pendekatan fungsi pertumbuhan dari struktur tanaman zinnia sehingga didapat model tanaman zinnia secara keseluruhan yaitu berumur 25 hari dalam bentuk virtual plant tanaman zinnia seperti dapat dilihat pada gambar 6. Fungsi pertumbuhan dihasilkan dari data pengamatan lapangan pada pertumbuhan struktur tanaman zinnia sesuai dengan waktu dalam siklus hidup tanaman, grafik pertumbuhan untuk batang pada gambar 4 . Data lapangan dirubah ke fungsi pertumbuhan $\mathrm{G}(\mathrm{t})$ 
(Somporn.C.A,dkk, 2004) sesuai dengan waktu pengamatan yang dilakukan dengan persamaan 1 .

$$
G(t)=L+\frac{U-L}{1+e^{m(T-t)}}
$$

di mana

L : nilai minimum panjang atau lebar.

U : nilai maksimum panjang atau lebar.

m : nilai kemiringan diperkirakan dari data mentah.

$\mathrm{T} \quad$ : waktu di (U-L)/2.

$\mathrm{t} \quad$ : waktu independen variabel.

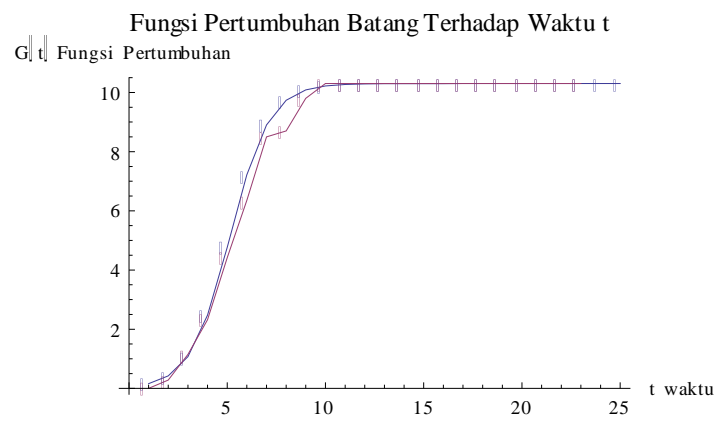

Gambar 4. Fungsi Pertumbuhan Struktur Batang Tanaman Zinnia

Nilai minimum dari variabel $L$, nilai maksimum dari variabel U, nilai kemiringan grafik dari variabel $m$ dan waktu $T$ didapat pada setiap komponen arsitektur tanaman zinnia seperti pada tabel 1.

Tabel 1. Nilai U, T, m dan T untuk simbol stalk, leaf dan bloom

\begin{tabular}{lllll}
\hline Simbol & Nilai L & Nilai U & Nilai m & Nilai T \\
\hline stalk & 0 & 10.3 & 0.9 & 4.4 \\
leaf & 0 & 6.6 & 0.9 & 4.1 \\
bloom & 0 & 7.2 & 0.8 & 4 \\
\hline
\end{tabular}

Setiap komponen dari arsitektur tanaman zinnia seperti stalk, leaf dan bloom akan dikontrol oleh fungsi pertumbuhan yang ditunjukkan pada produksi p1, p2, p3, p4 untuk produksi pada notasi p1 menjelaskan perubahan tunas, produksi pada notasi p2 menjelaskan perubahan perpanjangan batang, produksi pada notasi p3 menjelaskan perubahan ukuran daun, produksi pada notasi p4 menjelaskan perubahan ukuran bunga seperti gambar 5 .

\section{VISUALISASI MODEL KUANTITATIF PERTUMBUHAN TANAMAN}

Template MathEvolvica (Jacob, 1995) dapat mengimplemetasikan metoda L-System pada pemodelan pertumbuhan tanaman, template ini terdiri dari program kLSystem.m dan TurtleInterpretation.m sebagai inisialisasi implementasi metoda L-System. Pemodelan pertumbuhan tanaman zinnia yang dikodekan ke dalam program mathematica sesuai dengan metoda $L$-System dapat dilihat pada gambar 9, kemudian tiap kode dari metoda L-System akan dikonversi ke turtle bentuk grafik komputer, visualisasi model tanaman zinnia kalau sudah cocok berhenti jika diperlukan perubahan maka dilakukan perubahan model kuantitatif dan model kualitatif tanaman zinnia sesuai dengan metoda $L$ System.

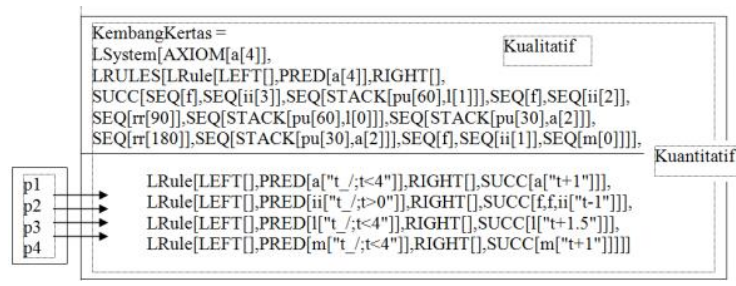

Gambar 5. kode program mathematica untuk pemodelan pertumbuhan tanaman zinnia

Dengan menggunakan Template Math Evolvica pada program mathematica didapat visualisasi pertumbuhan tanaman zinnia pada Gambar 6 dimulai dengan munculnya tunas yang dinotasikan sebagai sprout(4) dimana notasi ini tidak merepresentasikan bentuk grafik, produksi pertama untuk rule grammar adalah mengganti sprout dengan empat struktur stalks yang di ikuti dengan tiga struktur leaf, tiap struktur leaf terdiri dari dua daun leaf(0), untuk stalks(2) akan muncul cabang diatas dua daun leaf(0) Antara dua struktur leaf akan muncul dua tunas sebagai cabang tanaman dengan ditandai sprout(2). Dan pada ujung paling tinggi pada stalks direpresentasikan sebagai bloom(0), yang direpresentasikan sebagai bunga zinnia gambar 6.1, proses berikutnya adalah produksi kedua yaitu melanjutkan aturan rule grammar seperti proses pada produksi pertama yang dikatakan sebagai metoda rewriting gambar 6.2.
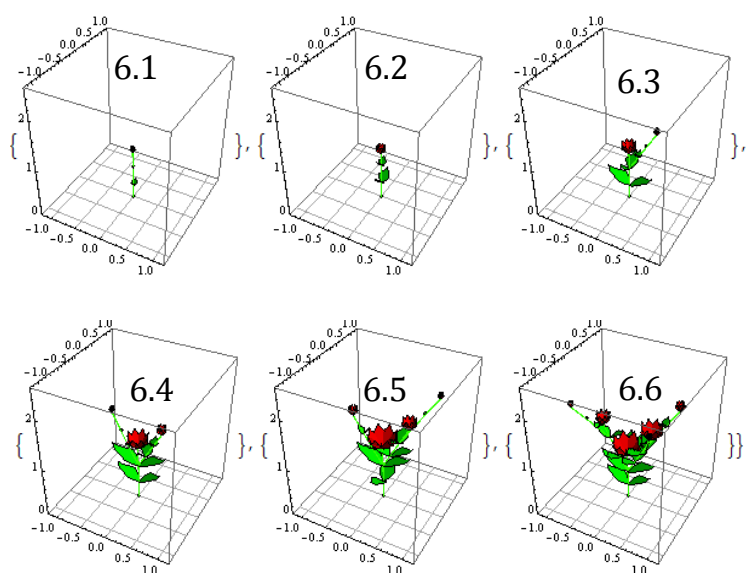

Gambar 6. Visualisasi pertumbuhan pemodelan pertumbuhan tanaman zinnia 
Visualisasi pertumbuhan tanaman zinnia dilakukan sampai proses pertumbuhan tanaman pada tahap keenam pada gambar 6 .

\section{KESIMPULAN}

Berdasar penerapan data pertumbuhan tanaman zinnnia, penerapan metoda L-System pada pemodelan pertumbuhan tanaman zinnia dapat mengidentifikasi pertumbuhan tanaman zinnia selama 25 hari dalam 6 tahap, dimana pada setiap tahap pertumbuhan tanaman dapat divisualisasikan.

\section{DAFTAR PUSTAKA}

[1] Brooks dan Peter, 2006, Metric for IT Service Management (Jan van bon, Ed), Zaltbommel : Van Haren Publishing.

[2] Chuai-Aree.S, Siripant.S dan Lursinsap.C, 2000, Animating Plant growth in L-System by Parametric functional symbols, Proc. Of Intern. Conf. on Intelligent Technology 2000, pp 135-143, December 13-15, University Bangkok, Thailand

[3] Hirafuji.M, 1991, A plant growth model by neural networks and L-System, Proc.9.Th IFAC Symp. Identification and System Parameter Estimation, Vol 3 Fukuoka, Japan, pp.997-1022

[4] Jacob.C, 2001, Illustrating Evolutionary Computation with Mathematica. Morgan Kaufmann Publishers, San Fancisco.

[5] James A. Freeman, 1994, Fuzzy Systems for Control Applications: The Truck BackerUpper, the Mathematica Journal, Miller Freeman Publications

[6] Karwowski.R dan Prusinkiewics.P, 2006, The L-System based plant modeling environment L-Studio 4.0. In Proceeding of the $4^{\text {th }}$ International Workshop on Functional Structural Plant Models, pp. 403405

[7] Mech. R dan Prusinkiewics.P, 1996, Visual Model of Plants Interacting with Their Environment, Proceedings of SIGGRAPH 96. In Computer Graphics Proceedings, Annual Conferenceseries, 1996, ACM SIGGRAPP, pp.397-410.

[8] Pachepsky.L.B, M.Kaul, C.Walthall, J.Lydon, H.Hong, C.S.T Daughtry, 2004, Soybean Growth and Development Visualized With L-Systems Simulation: Effect of temperature, International Jurnal of Biotronic Vol 33, 31-47
[9] Prusinkiewics.P, and Lindenmayer, 1990, The Algoritmic Beauty of Plant, SpringerVerlag, New York.

[10] Prusinkiewics.P, Jim Hanan, Mark Hammel dan Mech. R, 2003, L-System : from the Theory to Visual Models of Plants, Siggraph L-System and beyond, page 2.1-2.12

[11] Somporn.C.A , Suchada Siripant, Chidchanok Lursinsap, 2004, Animating Plant Growth in L-System By Parametric Functional Symbols, $4^{\text {th }}$ International Workshop on Functional Structural Plant Models.

[12] Suhartono, Mochamad Hariadi \& Mauridhi Hery Purnomo, 2011, Integration of Fuzzy System into Genetic L-System Programming based plant modeling environment with mathematica, Australian Journal of Basic and Applied, Vol. 5(11). pp. 1760-1765

[13] Suhartono, Mochamad Hariadi \& Mauridhi Hery Purnomo, 2011, Integration of Artificial Neural Network into Genetic LSystem Programming based plant modeling environment with mathematica, International Journal of Academic Research, Vol. 3. No. 6, I Part

[14] Suhartono, Mochamad Hariadi \& Mauridhi Hery Purnomo, 2010, Hybrid Genetic LSystem Method For Representing Indentification of Plant Growth Visualization, Proceding Seminar Nasional Teknologi Industri (SNTI), ISBN : 978-97918265-2-5 